\title{
Molecular bases of the interactions between luteoviruses and aphids *
}

\author{
SA Hogenhout, M Verbeek, F Hans, PM Houterman, M Fortass, F van der Wilk, \\ $\mathrm{H}$ Huttinga, JFJM van den Heuvel
}

DLO Research Institute for Plant Protection (IPO-DLO), PO Box 9060, NL-6700 GW Wageningen, the Netherlands

(Received 9 February 1996; accepted 13 February 1996)

\begin{abstract}
Summary - Many viruses infecting vertebrates or plants are transmitted by arthropod vectors in a circulative manner. This requires the virus to cross epithelial cells of the gut and salivary glands, and to resist the potentially hostile environment of the vector. Fundamental knowledge regarding the strategies adopted by these persistent viruses to overcome the transmission barriers mentioned is surprisingly meagre. Here we describe the involvement of endosymbiotic bacteria in the transmission of potato leafroll virus by its aphid vector Myzus persicae. Symbionin, the major protein synthesized and released into the haemolymph by the bacterial endosymbiont, was found to determine the persistent nature of the luteovirus in its vector. The virus displays a strong affinity to this protein $\left(M_{\mathrm{r}}=63000\right)$ which has high homology with the Escherichia coli heat shock protein groEL. The absence of symbionin in the haemolymph of aphids treated with antibiotics leads to rapid degradation of the major capsid protein of the virus and concomitant loss of infectivity.
\end{abstract}

persistent virus / endosymbiotic bacteria / symbionin

Résumé - Étude moléculaire des interactions entre les lutéovirus et les aphides. La plupart des virus de vertébrés et des virus de plantes sont transmis par des vecteurs arthropodes, selon un mode circulant. Ceci implique le passage des particules virales au travers des cellules épithéliales de l'intestin et de celles des glandes salivaires, ainsi que la résistance des particules virales à l'environnement potentiellement hostile du vecteur. Les stratégies adoptées par ces virus persistants afin de passer les barrières de transmission mentionnées ci-dessus sont peu connues. Nous décrivons ici le rôle d'une bactérie endosymbiotique au cours de la transmission du virus de l'enroulement de la pomme de terre par son vecteur qui est un aphide, Myzus persicae. Il a été montré que la symbionine, une protéine synthétisée de manière prédominante par la bactérie endosymbiotique de l'aphide et libérée dans l'hémolymphe de celui-ci, détermine la nature persistante du virus dans son vecteur. Le virus montre une forte affinité pour la symbionine ( $M, 63 K)$, qui possède de fortes homologies de séquence avec la protéine «heat-shock" groEL d'Escherichia coli. L'absence de symbionine dans l'hémolymphe d'aphides traités par des antibiotiques conduit à une rapide dégradation des particules virales et de leur pouvoir infectieux.

virus persistant / bactérie endosymbiotique / symbionine

* Communication presented to the Conference on Virus Diseases of the Poaceae - 1994. See agronomie vol 15, $\mathrm{n}^{\circ}$ 7-8. 


\section{INTRODUCTION}

Potato leafroll virus (PLRV) is a single-stranded RNA virus that belongs to the genus Luteovirus (Randles and Rathjen, 1995). Species of this genus infect a wide range of mono- and dicotyledonous plants in which they replicate almost exclusively in the phloem tissue (Van den Heuvel et al, 1995). Luteoviruses are transmitted by aphids in a circulative manner (Harrison, 1958; Sylvester, 1980). Briefly, this implies that virus particles are ingested along with phloem sap from infected host plants and transcellularly transported through the hindgut into the haemocoel. The acquired virus particles are retained in an infective form in the haemolymph for the aphids lifespan, apparently without replication (Eskandari et al, 1979). Upon contacting the accessory salivary glands, they may be transported through this gland, eventually arriving in the salivary duct from which they are released with the saliva during feeding of the aphid (Gildow and Gray, 1993). Luteoviruses display a high degree of vector specificity among aphid species. These well-developed specificities suggest an intimate association between a luteovirus and its vectors in which both surface domains of the viral capsid and sites or substances in the aphid are involved (Gildow, 1987). The role of the viral capsid proteins in conferring aphid transmissibility to a luteovirus has been convincingly demonstrated (Rochow, 1970, 1982; Brault et al, 1995). Studies on the identification on aphid-derived components interacting with luteoviruses have only recently been initiated (Van den Heuvel et al, 1994). Here we report on the development of ligand assays to ascertain whether particles of PLRV bind proteinaceous components from its major aphid vector, Myzus persicae (Sulz). Moreover, we elaborate on the role of symbionin, an aphid endosymbiont-derived protein for which the virus shows a high affinity.

\section{MATERIALS AND METHODS}

\section{Viruses, aphids and antibodies}

PLRV-Wageningen (Van der Wilk et al, 1989) was maintained on Physalis floridana (Van den Heuvel and Peters, 1990) and purified (Van den Heuvel et al, 1990). Other plant viruses used were kindly provided by colleagues at IPO-DLO, and CNRS-IBMP (Strasbourg). M persicae biotype WMp2 was reared on
Brassica napus $L$ subspecies oleifera (oilseed rape) in a greenhouse compartment at $20 \pm 3{ }^{\circ} \mathrm{C}$, with a $16 \mathrm{~h}$ photoperiod. Cohorts of nymphs differing in age by $24 \mathrm{~h}$ were produced by daily transfer of mature apterae to fresh host plants. Clones of field-collected Aphis fabae, A craccivora (from India), Acyrthosiphon pisum, Macrosiphum euphorbiae, Rhopalosiphum padi, Metopolophium dirhodum and Sitobion avenae were maintained at IPO-DLO. Bemisia tabaci and Frankliniella occidentalis derived from the Plant Protection Service (Wageningen) and the WAU Department of Virology, respectively.

Anti-idiotypic antibodies (AiAbs) were raised to PLRV-specific monoclonal antibodies (MAbs) (Van den Heuvel et al, 1990).

\section{Protein blots}

Isoelectric focusing (IEF) was carried out essentially as described in the literature (O'Farrell, 1975) using $2 \%$ $(\mathrm{v} / \mathrm{v}) \mathrm{pH} 3.5-10,1809$ Ampholine (Pharmacia) in both tube-gel monomer solution and IEF-sample buffer. One-day-old $M$ persicae nymphs, homogenized in IEFsample buffer ( $35 \mathrm{mg}$ wet weight $/ \mathrm{mL}$ ) were spun $\left(10000 \mathrm{~g}, 15 \mathrm{~min}, 4^{\circ} \mathrm{C}\right.$ ) and $50-\mu \mathrm{L}$ samples of the supernatant were loaded onto the tube gels. In the second dimension, proteins were separated by SDSpolyacrylamide gel electrophoresis (PAGE) and blotted onto nitrocellulose.

\section{Virus overlay assay and immunodetection}

Aphid proteins were tested for specific affinity for PLRV by incubating blots with purified PLRV particles $(10 \mu \mathrm{g} / \mathrm{mL})$ or PLRV-specific AiAbs $(1 \mu \mathrm{g} / \mathrm{mL})$ in PBSTween containing $2 \%$ polyvinylpyrrolidone $(\mathrm{w} / \mathrm{v})$ and $0.2 \%$ ovalbumin ( $w / v)$. This was followed by adding alkaline phosphatase-conjugated anti-PLRV antibodies or goat anti-rabbit secondary antibodies, respectively. Immobilized conjugates were visualized by the addition of 5-bromo-4-chloro-3-indoly|phosphate $p$-toluidine salt and nitroblue tetrazolium chloride in $0.1 \mathrm{M}$ ethanolamine- $\mathrm{HCl}, \mathrm{pH} 9.6$, containing $4 \mathrm{mM} \mathrm{MgCl}_{2}$.

\section{Immunogold labelling}

One-day-old $M$ persicae nymphs were fixed overnight in $0.1 \mathrm{M}$ cacodylate buffer, $\mathrm{pH} 7.2$, containing $4 \%(\mathrm{v} / \mathrm{v})$ paraformaldehyde and $0.1 \%(\mathrm{v} / \mathrm{v})$ glutaraldehyde, dehydrated, and embedded in LR Gold (The London Resin Co Ltd). Ultra-thin sections mounted on nickel grids were labelled with $2.5 \mu \mathrm{g}$ AiAbs per $\mathrm{mL}$ of PBS for $3 \mathrm{~h}$ at RT followed by a $1.5 \mathrm{~h}$ exposure to goat antirabbit antibodies linked to gold particles $(10 \mathrm{~nm}$ diameter). Sections were stained with $2 \%$ uranyl acetate and lead citrate and examined using a Philips CM12 electron microscope. 


\section{RESULTS AND DISCUSSION}

\section{Binding of PLRV to aphid-derived components}

To test whether PLRV showed affinity to protein components from its aphid vector, $M$ persicae, we separated whole-body extracts of the aphid (fig $1 \mathrm{~A}$ ) by two-dimensional SDS-polyacrylamide gel electrophoresis, transferred the proteins to nitrocellulose and probed them with purified virus. In this way five proteins were resolved that displayed a virus-binding capacity (fig $1 \mathrm{~B}$ ). The protein with the highest affinity for the virus was identified and its role in virus transmission investigated. This protein, called $\mathrm{P} 63$ had a $M_{\mathrm{r}}$ of 63000 and an isoelectric point between 5.8 and 6.0. P63 was also selected because it reacted with AiAbs (AiAb \#5 [fig 1C] and AiAb \#6 [data not shown]) raised to the MAbs WAU-A5 and -A6 which have been shown to recognize topologically-related surface epitopes of the viral capsid of PLRV (Van den Heuvel et al, 1990).

PLRV-binding proteins were not found in extracts of whiteflies ( $B$ tabacl) or thrips ( $F$ occidentalis) which transmit species of the genera 'subgroup III gemenivirus' and Tospovirus, respectively, in a circulative manner. P63 did not exhibit affinity toward several other vector-borne plant viruses, tobacco mosaic virus, on PLRVspecific anti-idiotypic antibodies other than \#5 and \#6 P63 (Van den Heuvel et al, 1994).

Symbionin readily binds purified PLRV and other luteoviruses, beet western yellows, bean leafroll, and barley yellow dwarf virus (fig 2) in an enzyme-linked immunosorbent-based assay. In this assay, native symbionin was trapped by a polyclonal antibody to symbionin on the solid phase. Other vector-borne plant viruses previ-
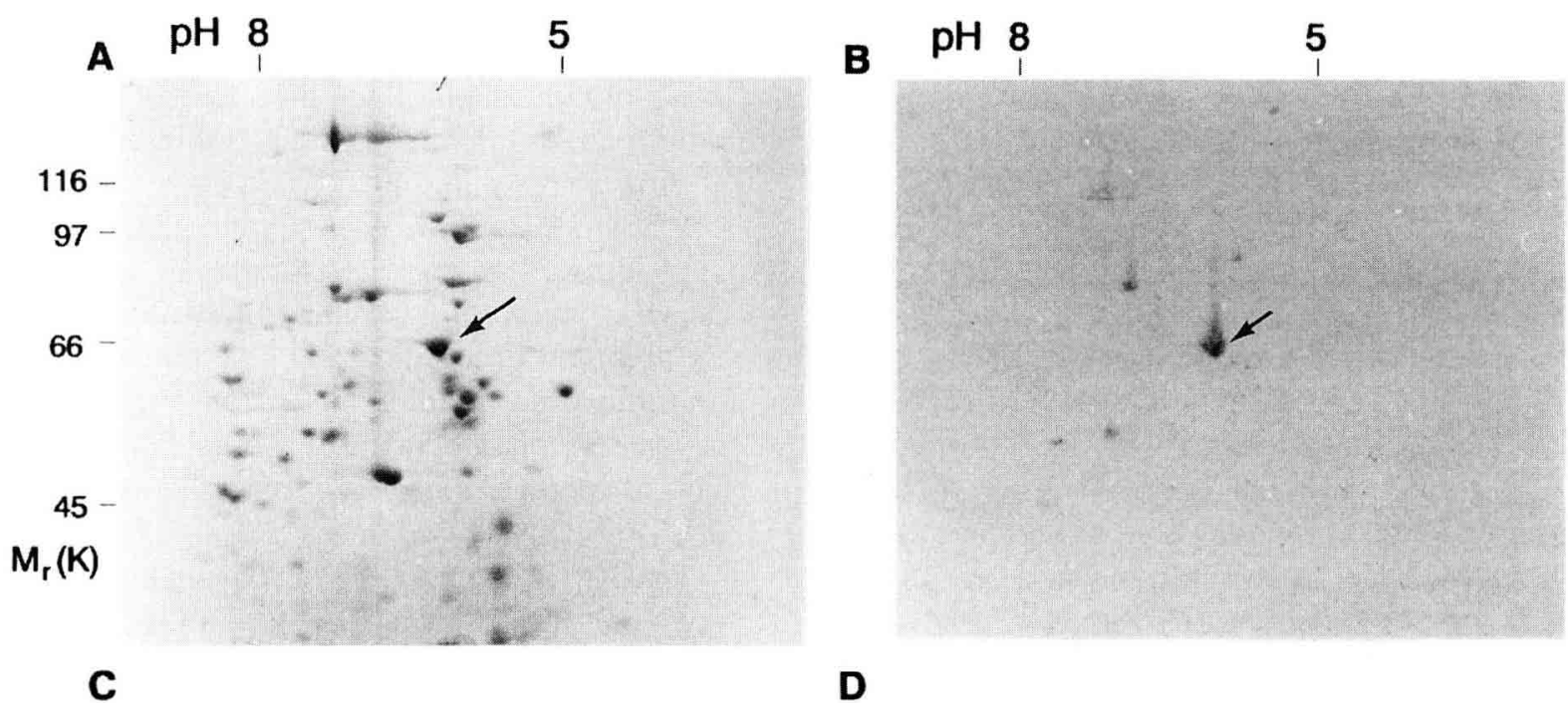

D
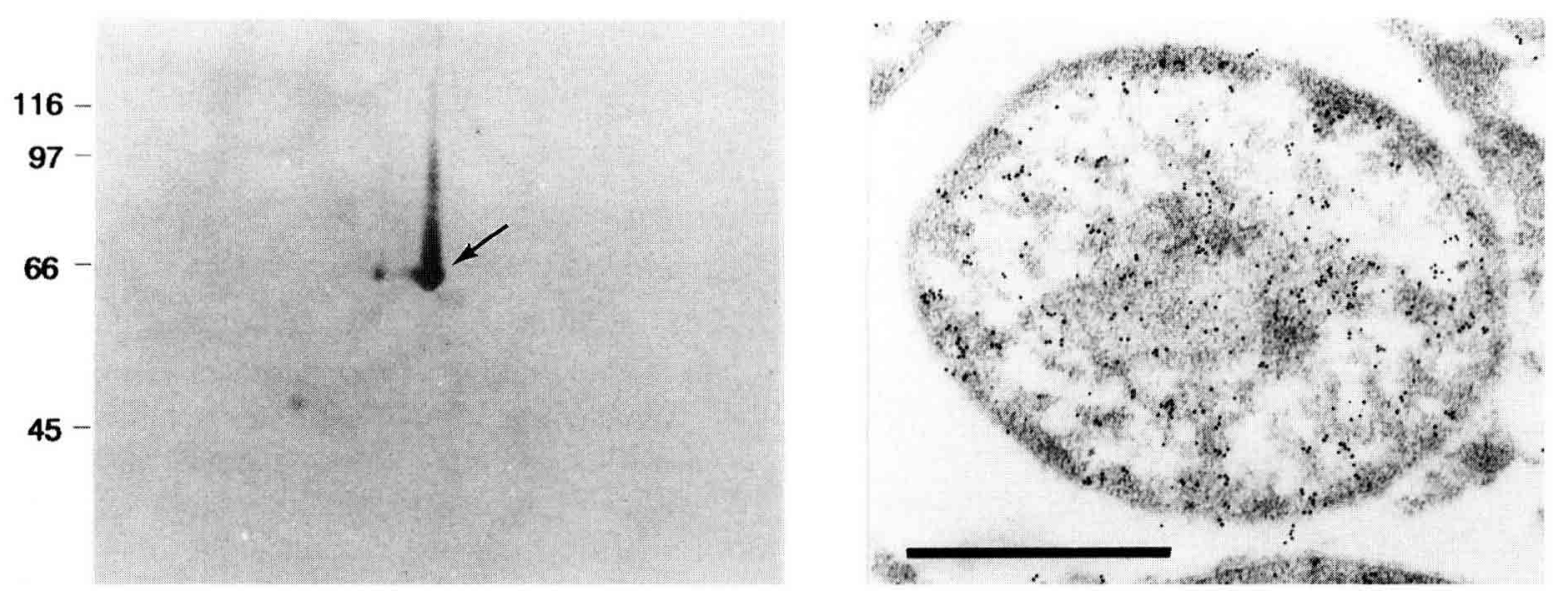

Fig 1. Identification of PLRV-binding proteins in homogenates of Myzus persicae and the localization of symbionin (P63) in the primary endosymbiont of the aphid. (A) Two-dimensional (2D) profile of whole-body proteins of $M$ persicae stained with Coomassie brilliant blue R250. (B) Immunoblots of 2D separated whole-body proteins of $M$ persicae decorated with purified PLRV, and (C) anti-idiotypic antibody \#5 (AiAb \#5), respectively. The position of symbionin is marked by an arrow. (D) Electron micrograph showing immunogoldlabelling of the primary endosymbionts in the mycetocyte of $M$ persicae using AiAb \#5. Bar represents $1 \mu \mathrm{m}$. 
ously tested (Van den Heuvel et al, 1994), as well as carnation ringspot virus and tobacco mosaic virus did not bind. The PLRV-binding capacity was not restricted solely to symbionin from $M$ persicae. Symbionin-like proteins from a number of aphid species of the Aphidinae also showed binding to PLRV in immunoblots (fig 3). Although most species of this subfamily have not been reported to transmit PLRV, our finding is consistent with the observation that non-vector aphids also can acquire and retain luteoviruses in their haemolymph (Rochow and Pang, 1961; Massalski and Harrison, 1987). Vector specificity seems to be determined at the level of the accessory salivary gland (Gildow and Gray, 1993).

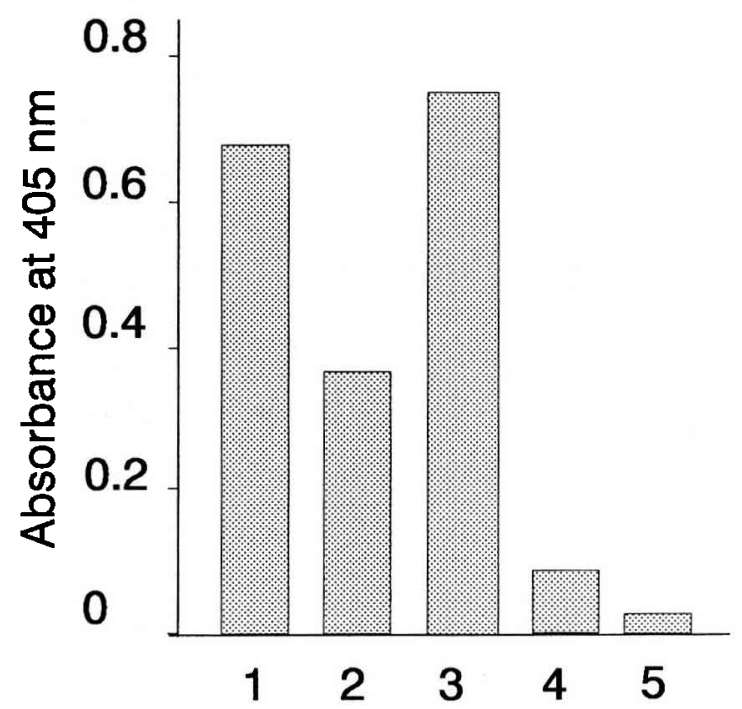

Fig 2. Enzyme-linked immunosorbent-based in vitro binding assay of luteoviruses to native symbionin of $M$ persicae. 1 , potato leafroll virus; 2 , beet western yellows virus; 3 , bean leafroll virus 4 , barley yellow dwarf virus; 5 , carnation ringspot virus (negative control).

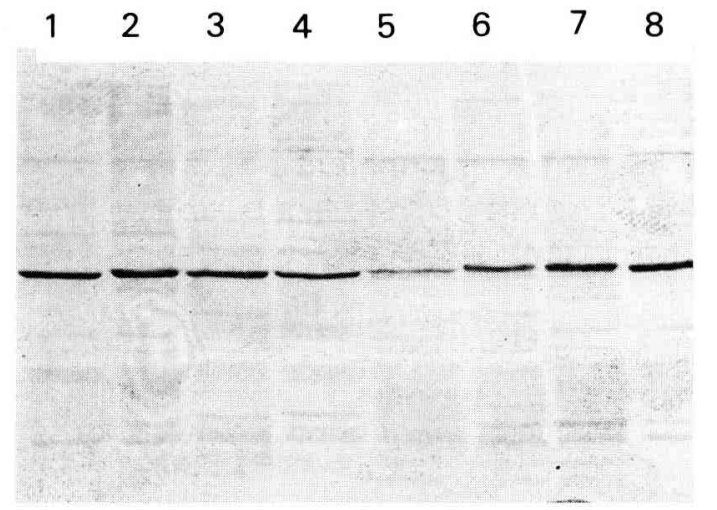

Fig 3. Binding of purified PLRV to symbionin-like molecules of Myzus persicae (1), Macrosiphum euphorbiae (2), Aphis fabae (3), A craccivora (4), Rhopalosiphum padi (5), Sitobion avenae (6), Metopolophium dirhodum (7), and Acyrthosiphon pisum (8).

\section{Identification and localization of symbionin}

Immunogold-labelling experiments on ultra-thin sections of $M$ persicae using AiAb \#5 showed that the antibody specifically tagged the cytoplasm of the primary endosymbiont of the aphid (fig 1D). These Gram-negative bacteria belong to the genus Buchnera which diverged from Escherichia coli about 420 million years ago (Unterman et al, 1989), and are found in the haemocoel of the aphid. The endosymbionts are harboured in specialized host-derived polyploid cells, called mycetocytes (Buchner, 1965). In vivo radiolabelling studies of endosymbiont proteins in the pea aphid, $A$ pisum, showed that synthesis is almost exclusively directed to one protein with a $M_{\mathrm{r}}$ of 63000 , which is tentatively named symbionin (Ishikawa, 1982). Symbionin-like molecules are found in all major aphid groups except the Phylloxeridae, are immunologically closely related, and are highly homologous to the $E$ coli heat shock protein groEL, a member of the chaperonin-60 family of molecular chaperons (Ohtaka et al, 1992). Based on the biochemical characterization of the protein, the abundance in the endosymbiont of the aphid, and the $100 \%$ homology of the $35 \mathrm{~N}$-terminal amino acids to symbionin of $A$ pisum we concluded that P63 from $M$ persicae is symbionin (Van den Heuvel, 1994). Symbionins are, like groEL, 14-subunit homooligomers composed of two stacked rings of seven subunits each (Hara and Ishikawa, 1990). The diameter of native symbionin is about $7 \mathrm{~nm}$ (fig 4).

Besides the presence of symbionin in the cytoplasm of the symbiotic bacteria, it is also readily detected in the haemolymph of the aphid. It probably is released by exclusion of degenerating endosymbionts by the mycetocytes (Ponsen, 1972) although active secretion can not be excluded.

\section{Role of symbionin in luteovirus transmission}

It is likely that PLRV particles suspended in the haemolymph interact with symbionin, since purified PLRV readily binds to native symbionin in vitro. In order to investigate the role of P63 in PLRV transmission we subjected one-day-old $M$ persicae nymphs to a tretracycline treatment ( $50 \mu \mathrm{g} / \mathrm{mL}$ of artificial diet) $24 \mathrm{~h}$ prior to virus acquisition. Inhibition of prokaryotic protein synthesis by the antibiotic selectively eliminated this protein from the haemolymph (fig $5 \mathrm{~A}$ ) without 
Fig 4. Electron micrograph showing purified symbionin.

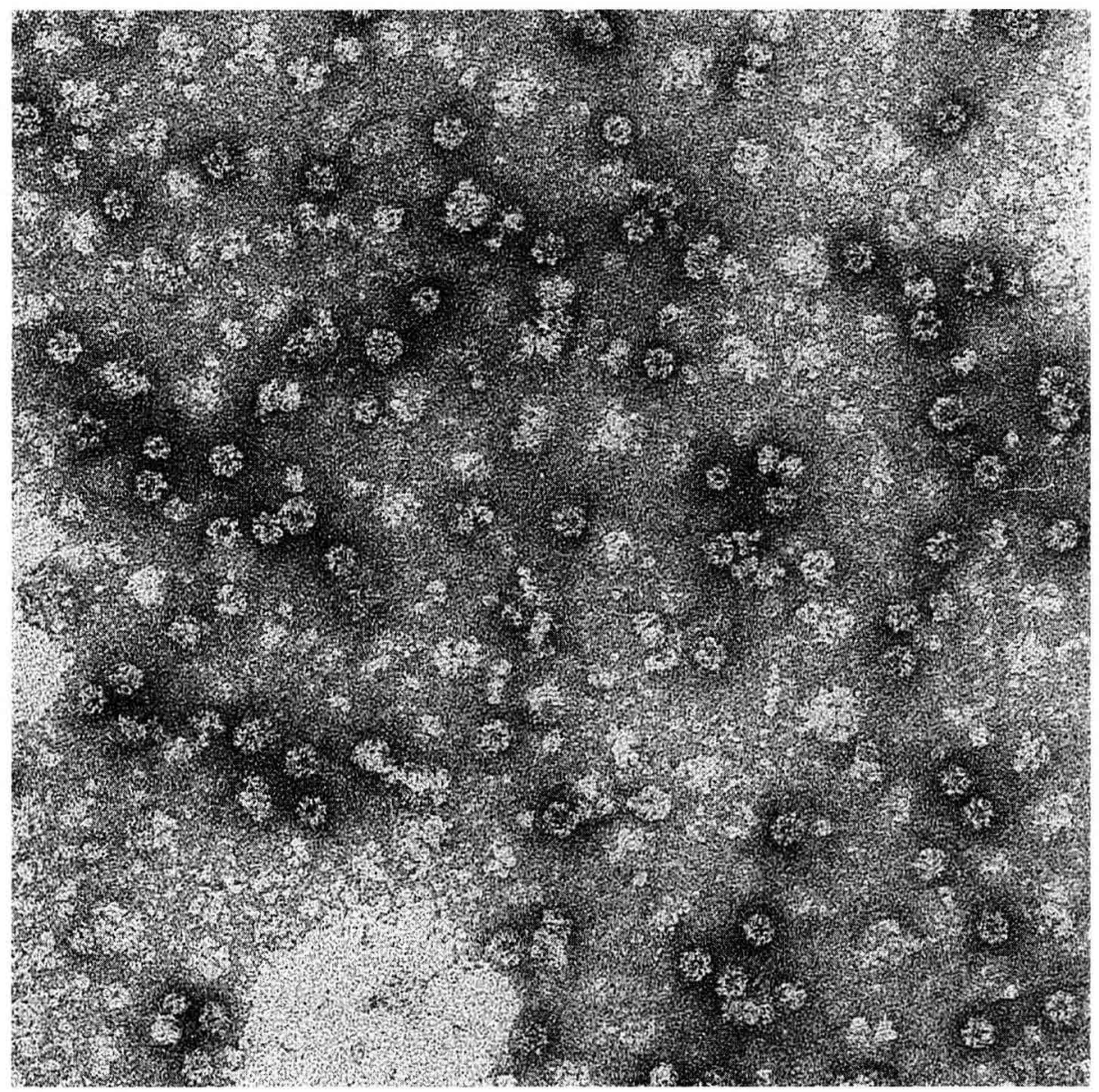

markedly affecting aphid feeding behaviour. Virus transmission by the antibiotic-treated aphids was reduced by more than $70 \%$ (fig $5 \mathrm{~B}$ ). The major coat protein species of PLRV of $M_{\mathrm{r}} 23000$ was prone to degradation in the antibiotic-treated aphids (fig 5C), which would result in an increased exposure of viral RNA to enzymic breakdown and concomitant loss of infectivity.

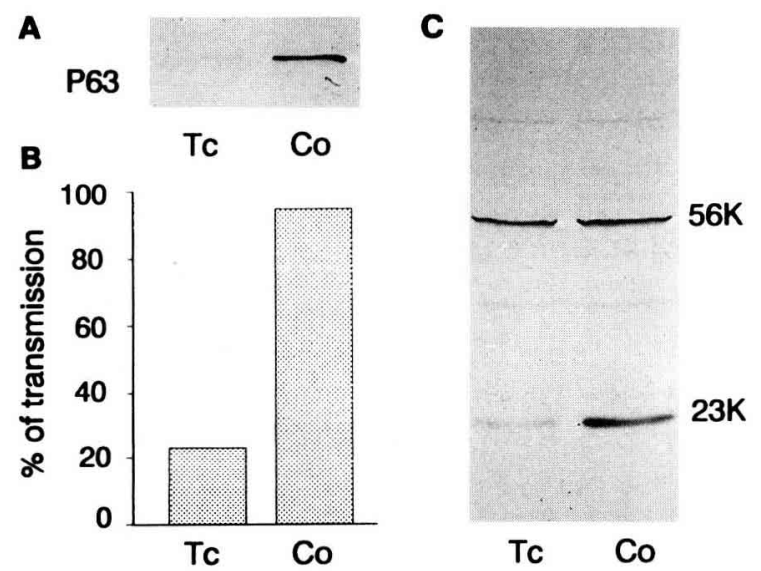

Fig 5. The effect of tetracycline treatment of Myzus persicae on the presence of symbionin (P63) in the haemolymph of the aphid (A), the transmission of PLRV (B), and capsid integrity of acquired virus (C). Tc: tetracycline treated; Co: control (no antibiotic added).
Strikingly, the other virion-associated structural protein $\left(M_{r} 56000\right)$ was still present in amounts similar to the control group of aphids not treated with the antibiotic.

\section{Transovarial transmission}

Symbiotic bacteria have only been implicated in the transmission of rice dwarf virus (RDV; genus Phytoreovirus) by leafhoppers (Nasu, 1965). RDV is transmitted in a circulative, replicative manner by leafhoppers. Electron microscopy (EM) studies revealed that the virus binds to the surface of the L-symbiont of the leafhopper. Since these bacterial symbionts are transovarially transmitted, RDV was also carried to the next generation.

Symbiotic bacteria of aphids are transmitted transovarially to their offspring as well. EM observations of ultra-thin sections of $M$ persicae neonates showed a number of embryos in different stages of development. In some of these embryos, endosymbiotic bacteria were clearly visible in the blastocoel; the majority were still uninfected (not shown). The bacteria enter the 


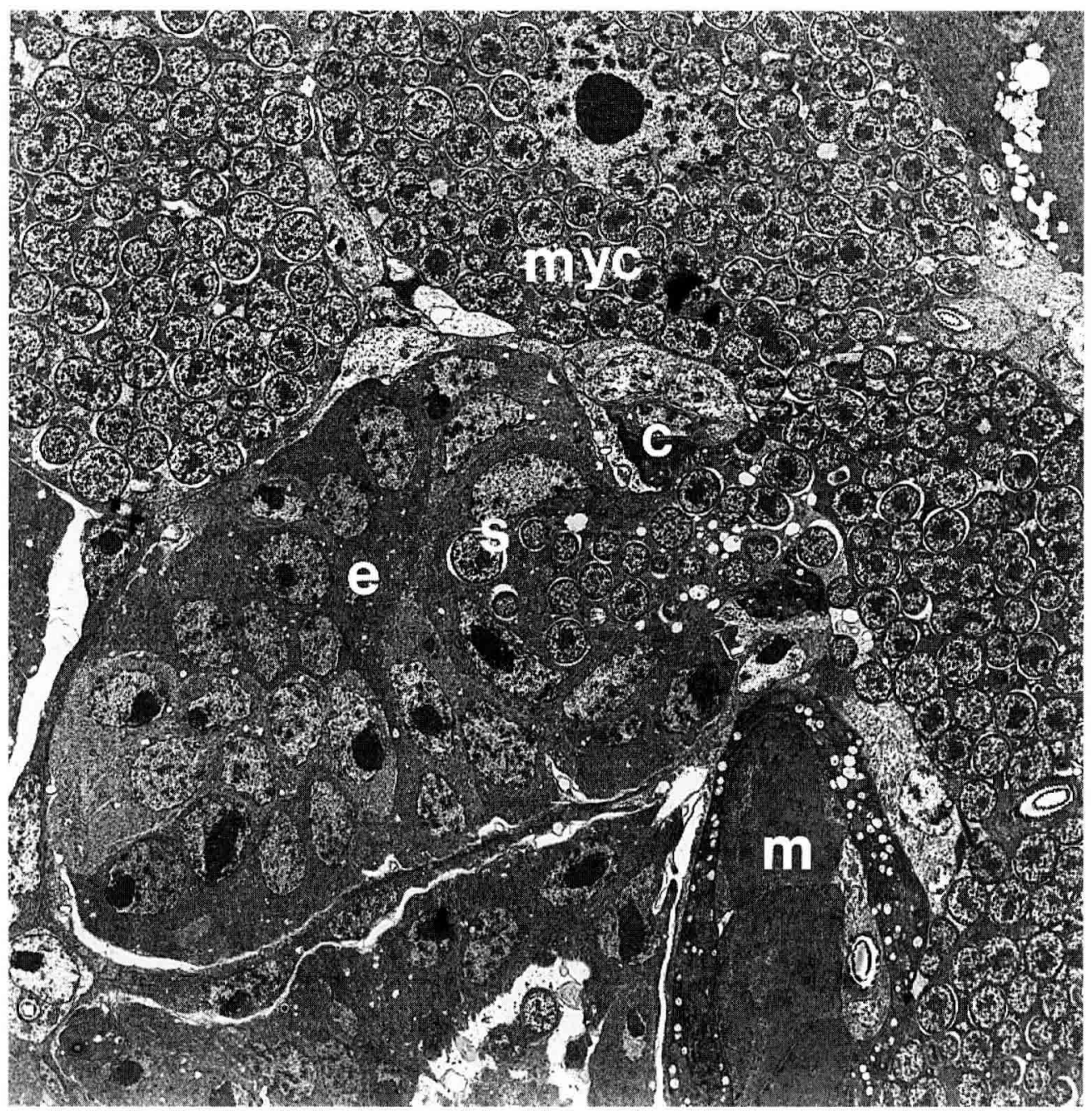

Fig 6. Transovarial transmission of endosymbiotic bacteria in one-day-old nymphs of Myzus persicae. con: conical cell; e: embryo; m: muscle; myc: mycetocyte; s: symbiont

embryo in the blastula stage (fig 6). A few cells in the blastoderm develop into conical structures forming the blastopore, a canal that facilitates the influx of endosymbiotic bacteria from a maternal mycetocyte contiguous with the follicular epithelium (fig 6). Transovarial transmission of luteoviruses has never been observed. A direct interaction between the endosymbiotic bacteria of aphids and a luteovirus, as seen for RDV and leafhoppers, is therefore unlikely to occur.

\section{Concluding remarks and prospects}

The presence of the endosymbiont protein symbionin in the haemolymph of aphids is of eminent importance to the persistent nature of PLRV. It is envisaged that virus particles in the haemolymph associate (transiently) with this protein which retards proteolytic breakdown of the virus in the aphid. Although the coexistence of symbiotic organisms in arthropods is well documented and widespread, it is surprising that there is very little information regarding their ability to influence vector competence (Hardy et al, 1983). What is more, such knowledge may open up novel ways of preventing circulative transmission of a wide range of arthropod-borne viruses and parasites - not only by disturbing the interactions between endosymbiotic bacteria or proteins and disease agents, but also through the expression of recombinant proteins which may interfere with particular phases of the infection cycle of viruses and parasites in their vectors. In closing, we believe that the application of binding assays similar to the ones recently described (Schmidt et al, 1994; Van den Heuvel et al, 1994) will contribute significantly to understanding the molecular basis of virus transmission by invertebrate vectors.

\section{ACKNOWLEDGMENT}

The authors acknowledge DW Thornbury for discussions. 


\section{REFERENCES}

Brault V, Van den Heuvel JFJM, Verbeek M, ZieglerGraff V, Reutenauer A, Herrbach E, Garaud JC, Guilley H, Richards K, Jonard G (1995) Aphid transmission of beet western yellows luteovirus requires the minor capsid read-through protein P74. EMBO J $14,650-659$

Buchner P (1965) Endosymbiosis of Animals with Plant Microorganisms. Interscience Publishers, New York, $909 \mathrm{pp}$

Eskandari F, Sylvester ES, Richardson J (1979) Evidence for lack of propagation of potato leafroll virus in its aphid vector, Myzus persicae. Phytopathology 69, 45-47

Gildow FE (1987) Virus-membrane interactions involved in circulative transmission of luteoviruses by aphids. Curr Top Vector Res 4, 93-120

Gildow FE, Gray SM (1993) The aphid salivary gland basal lamina as a selective barrier associated with vector-specific transmission of barley yellow dwarf virus. Phytopathology 83, 1293-1302

Hara E, Ishikawa H (1990) Purification and partial characterization of symbionin, an aphid endosymbiont-specific protein. Insect Biochem 20, 421-427

Hardy JL, Houk EJ, Kramer LD, Reeves WC (1983) Intrinsic factors affecting vector competence of mosquitoes for arboviruses. Annu Rev Entomol 28 , 229-262

Harrison BD (1958) Studies on the behavior of potato leaf roll and other viruses in the body of their aphid vector Myzus persicae (Sulz). Virology 6, 265-277

Ishikawa $\mathrm{H}$ (1982) Host-symbiont interactions in protein synthesis in the pea aphid, Acyrthosiphon pisum. Insect Biochem 12, 613-622

Massalski PR, Harrison BD (1987) Properties of monoclonal antibodies to potato leafroll luteoviruses and their use to distinguish virus isolates differing in aphid transmissibility. J Gen Virol 68, 1813-1821

Nasu S (1965) Electron microscopic studies on transovarial passage of rice dwarf virus. Jpn $J$ Appl Entomol Zool 9, 225-237

O'Farrell PH (1975) High resolution two-dimensional electrophoresis of proteins. J Biol Chem 250, 40074021

Ohtaka C, Nakamura H, Ishikawa H (1992) Structure of chaperonins from an intracellular symbiont and their functional expression in $E$ coli groE mutants. $J$ Bacteriol 174, 1869-1874
Ponsen MB (1972) The site of potato leafroll virus multiplication in its vector, Myzus persicae. Meded Landbouwhogesch Wageningen 72-16

Randles JW, Rathjen JP (1995) Genus luteovirus. In: Virus Taxonomy, Sixth Report of the International Committee on Taxonomy of Viruses (FA Murphy, CM Fauquet, DHL Bishop, SA Ghabrial, AW Jarvis, GP Martelli, MA Mayo, MD Summers, eds), Springer-Verlag, Wien, 379-383

Rochow WF (1970) Barley yellow dwarf virus: phenotypic mixing and vector specificity. Science 167 , 875-878

Rochow WF (1982) Dependent transmission by aphids of barley yellow dwarf luteoviruses from mixed infections. Phytopathology 72, 302-305

Rochow WF, Pang E (1961) Aphids can acquire strains of barley yellow dwarf that they do not transmit. Virology 15, 382-384

Schmidt I, Blanc S, Esparandieu P, Kuhl G, Devauchelle G, Louis C, Cerutti M (1994) Interaction between the aphid transmission factor and virus particles is a part of the molecular mechanism of cauliflower mosaic virus aphid transmission. Proc Natl Acad Sci USA 91, 8885-8889

Sylvester ES (1980) Circulative and propagative virus transmission by aphids. Annu Rev Entomol 25, 257286

Unterman BM, Baumann P, McLean LD (1989) Pea aphid symbiont relationships established by analysis of 16S rRNA. J Bacteriol 171, 2970-2974

Van den Heuvel JFJM, De Blank DM, Goldbach RW, Peters D (1990) A characterization of epitopes on potato leafroll virus coat protein. Arch Virol 115, 185-197

Van den Heuvel JFJM, De Blank CM, Peters D, Van Lent JWM (1995) Localization of potato leafroll virus in leaves of secondarily-infected potato plants. Eur $J$ Plant Pathol 101, in press

Van den Heuvel JFJM, Peters D (1990) Transmission of potato leafroll virus in relation to honeydew excretion. Ann Appl Biol 116, 493-502

Van den Heuvel JFJM, Verbeek M, Van der Wilk F (1994) Endosymbiotic bacteria associated with circulative transmission of potato leafroll virus by Myzus persicae. J Gen Virol 116, 493-502

Van der Wilk F, Huisman MJ, Cornelissen BJC, Huttinga H, Goldbach R (1989) Nucleotide sequence and organization of potato leafroll virus genomic RNA. FEBS Lett 245, 51-56 